\title{
STRATEGI PEMBELAJARAN MATEMATIKA MENYENANGKAN SISWA (MMS) BERBASIS METODE PERMAINAN MATHEMAGIC, TEKA-TEKI DAN CERITA MATEMATIS
}

\author{
Maswar Maswar \\ Universitas Ibrahimy, Situbondo, Indonesia \\ maswar@ibrahimy.ac.id
}

\begin{abstract}
:
Until now there are still many students who consider aboaut metematics as a school subject that is considered scary and boring. Because it contains many difficult and meticulous formulas. Though mathematics is a very important subject to be learned along with the progress of Science and Technology increasingly sophisticated in Era 4.0. Through Mathematics with all its applications, it creates many kinds of increasingly sophisticated contemporary technologies. Mathematics can be said to be the mother of all sciences. Therefore, mathematics is very important to be taught to students and must be able to be well received and enjoyable. Therefore it is necessary to look for a development of mathematical learning concepts that are in accordance with the characteristics of students namely fun mathematics learning strategies that can make students happy when studying, both at school and at private institutions. In this paper discusses focused for fun learning strategies based on mathematical game methods, Mathematical Puzzles, and Mathematical Stories.
\end{abstract}

Keywords: MMS, Game Methods, Puzzles, Mathematical Stories.

\section{PENDAHULUAN}

Indonesia sebagai Negara berkembang yang sedang menuju kemajuan di mata bangsa-bangsa Internasional sangat memerlukan ketangguhan dari berbagai aspek, khususnya ketangguhan dari Sumber Daya Manusia (SDM). Sumber Daya Manusia adalah modal yang paling penting untuk menciptakan Negara yang maju, karena dengan bangsa yang berkualitas baik dari segi intelektual, emosional dan spritualnya, Negara Indonesia akan mengalami revolusi yang signifikan. Salah satu contoh untuk mengembangkan industri dan beberapa aspek lain, tidak bisa kita pungkiri, bahwa semua itu memerlukan sumber daya manusia yang mampu untuk mengembangkannya.

Membentuk bangsa yang handal memerlukan sebuah cara, salah satu cara yang sangat efektif adalah melalui proses pendidikan. Pendidikan merupakan bagian integral dalam pembangunan. Proses pendidikan tidak dapat dipisahkan dari proses pembangunan sendiri, ketika kualitas pendidikan kita rendah maka bisa kita katakan bahwa Indonesia perkembangannya akan terhambat.

Seorang guru memiliki tanggungjawab dan tugas yang harus dilaksanakan sesuai dengan tuntutan profesi guru dan yang paling utama adalah memajukan dan membimbing siswa dalam proses belajar (Samsudin, Tarbiyah, \& Situbondo, 2018). Tentunya segala proses belajar mengajar yang dilaksanakan harus dirancang dengan baik, namun juga tidak kaku. Rancangan pembelajaran yang baik setidaknya mengacu pada Silabus dan RPS. Sedangkan, tidak kaku yang dimaksudkan ialah menerapkan berbagai metode yang variatif, inovatif dan 
menarik yang dapat menstimuli siswa untuk semangat belajar, lebih-lebih pada mata pelajaran matematika.

Metode belajar yang variatif, inovatif dan menarik menjadikan proses belajar matematika di kelas menjadi terhibur dan menyenangkan siswa. Metode memiliki implikasi terhadap motivasi siswa dalam belajar. Oleh karena itu, pemilihan metode harus tepat guna dan tidak monoton sehingga siswa tidak merasa jenuh dalam menerima materi matematika dari gur. Tugas guru tidak hanya mengajar saja, tapi jugam menimbulkan minat siswa terhadap apa yang mereka pelajari. Ada guru yang cuek saja, guru-guru sepertiini mengahbiskan masa mereka di dalam kelas semata-mata hanya untuk menuangkan bahan pembelajaran kepada siswa. Mereka tidak peduli isi pembelajaran yang mereka ajarkan atau yang mereka terangkan itudapat diterima oleh siswa untuk dijadikan sebagai milikinya atau tidak. Mereka tidak memperhatikan apakah bahan yang mereka ajarkan itu bermanfaat dan mempengaruhi tingkah laku atau perkembangan siswa ke arah yang lebih positif. Guru-guru sepertiini tidak menyadari bahwa siswa-siswa yang tidak berminat tidak akan dapat menerima pelajaran dengan baik. Yang pada akhirnya peserta didiknya enggan rajin masuk sekolah (Samsudin et al., 2018).

Peranan guru dalam pembelajaran matematika sangatlah penting berkenaan dengan metode yang digunakan dalam mengajar siswa. Tinggi rendahnya hasil belajar siswa salah satunya bergantung pada gurunya. Rendahnya hasil belajar siswa dalam pembelajaran matematika disebabkan oleh banyak faktor. Salah satu di antaranya adalah faktor guru yang kurang bisa menciptakan iklim belajar yang menyenangkan bagi siswa. Seorang guru pada pelajaran matematika dituntut untuk bisa menciptakan suasana belajar yang aktif, kreatif dan juga menyenangkan bagi siswa (Kritiyono, 2008). Dengan terciptanya suasana yang demikian maka dapat menumbuhkan bahkan meningkatkan minat siswa pada matematika.

Syah (Suwarno, 2016) menyatakan bahwa minat dapat diartikan sebagai suatu kecenderungan dan kegairahan yang tinggi atau keinginan yang besar terhadap sesuatu. Sedangkan menurut Safari (2005) mengatakan bahwa siswa dikatakan berminat dalam pembelajaran jika memenuhi indikator minat belajar, yaitu perasaan snang, ketertarikan, perhatian dan keterlibatan yang aktif dalam pembelajaran.

Bertolak belakang dengan minat yang seharusnya dimiliki siswa dalam belajar matematika, hampir disetiap isu pendidikan dan pembelajaran, yang paling banyak disoroti oleh masyarakat adalah tentang kemampuan siswa di bidang ilmu eksak khususnya matematika yang dikenal oleh siswa sebagai pelajaran yang tidak menyenangkan dan membosankan. Padahal yang kita ketahui bahwa matematika adalah ilmu mendasar dalam kehidupan manusia, khususnya dalam pengembangan ilmu-ilmu terapan. Bahkan dapat kita katakan bahwa matematika merupakan ibu atau induk dari berbagai ilmu pengetahuan yang dipelajari oleh manusia. Hal ini sesuai dengan pendapat Carl Friedrich Gauss (Rosa, 2017) mengatakan bahwa "mathematics is the queen of sciences". Menurut Thalhah, Tohir, Nguyen, Shankar, \& Rahim (2019) mengatakan bahwa "mathematics is the bedrock of any contemporary order of science". Matematika juga cukup berperan penting dalam memajukan Negara Indonesia dan untuk mensejahterakan bangsa Indonesia melalui perkembangan Ilmu Pengetahuan dan Teknologi (IPTEK) yang tidak lepas dari dasar ilmu yaitu matematika. Ini terbukti bahwa ilmu matematika adalah 
disiplin ilmu yang menjadi dasar untuk mempelajari tentang ilmu pengetahuan lainnya. Matematika adalah mata pelajaran yang penting untuk dipelajari, sehingga yang terjadi seharusnya mata pelajaran matematika menjadi mata pelajaran yang menyenangkan bagi anak didik, sehingga nantinya anak didik akan tertarik, dan gemar, untuk mempelajari mata pelajaran matematika dan pada akhirnya nilai yang diperoleh anak didik sangat memuaskan serta anak didik dapat mengaplikasikan matematika yang telah di pelajari dalam kehidupan sehari-hari. Dengan demikian ilmu pengetahuan matematika yang dimiliki nampak bermanfaat bagi dirinya dan orang lain.

Realitas yang sering kita jumpai di lapangan, hingga saat ini masih sangat banyak anak didik yang menganggap matematika sebagai mata pelajaran yang menakutkan sekaligus momok menyebalkan. Selain dianggap sulit, matematika juga dianggap sebagai salah satu dan bahkan nomor satu mata pelajaran disekolah yang sangat membosankan. Hal ini tentu juga tidak menutup kemungkinan selain memang materi yang dipelajari sulit, guru dalam menyajikannya kurang membuat siswa termotivasi untuk belajar matematika.

Hal ini sering diungkap oleh beberapa media cetak atau elektronik. Dalam media, baik cetak maupun elektronik, sering kita jumpai informasi tentang masalah yang terkait dengan pendidikan, misal: Daniel mengatakan bahwa sekarang ini banyak sekolah yang megah, tapi gurunya megah-megahi (Jawa Pos, 18 februari 2009). Tentunya ungkapan Daniel tersebut Matematika juga. Hal itu di dasari oleh banyaknya berita "miring" yang dimuat media tentang pendidikan Matematika,misalnya: Matematika masih menjadi momok (Jawa Pos 27 April 2007), Matematika paling jeblok (Jawa Pos 29 Mei 2007), Guru Matematika bikin kecewa (Jawa Pos 7 Januari 2008), Matematika masih paling ditakuti (Nurani Edisi 368), mengaku sulit di mapel Matematika (Jawa Pos 14 Januari 2008). Tentunya masih banyak artikel "tidak sedap" yang terkait dengan pendidikan Matematika yang terdapat dalam media yang dapat (Placeholder3) dijumpai.

Mengapa anak didik cenderung beranggapan buruk terhadap matematika?, sungguhkah matematika itu sulit, menakutkan, dan membosankan?.

Anggapan buruk anak didik terhadap matematika yang sering kita dengar hingga saat ini adalah bukan hanya karena materi matematika yang memang sedikit terkesan sulit dibandingkan mata pelajaran lainnya.Tetapi karena dalam merangkai pembelajaran, guru pada umumnya terbiasa dengan model atau metode standar, yakni pembelajaran yang bermula dari rumus, menghafalnya, kemudian ditetapkan dalam contoh soal.

Metode seperti ini yang mengakibatkan matematika bak kumpulan rumus yang menyeramkan, menakutkan, dan sulit dipelajari oleh siswa. Metode yang demikian juga membuat anak didik kurang termotivasi dan merasa tertekan belajar matematika. Karena tidak sedikitpun dari materi matematika yang dapat ditunjukkan untuk menyenangkan bagi anak didik. Akibat dari model atau metode yang demikian, hinggga saat ini siswa cenderung beranggapan buruk terhadap matematika.

Dari beberapa anggapan buruk anak didik terhadap matematika, tentu hal tersebut merupakan problem besar yang harus segera kita carikan solusinya. Solusi yang ideal yang dapat mengurangi pemberitaan negatif tentang pelajaran matematika dan dapat meningkatkan kualitas pengetahuan anak didik di bidang 
mata pelajaran matematika menjadi baik, maka sangat perlu guru memiliki starategi mengajar yang mampu membuat anak senang belajar secara mendalam dan maksimal tentang ilmu matematika.

Salah satu alternatif yang dapat ditawarkan sebagai solusi adalah dengan membuat pembelajaran itu lebih inovatif. Sebuah inovasi baru dunia pendidikan diperlukan untuk memicu perkembangan media pendidikan di Indonesia. Menurut penelitian yang telah dilakukan oleh Awan, Noureen, dan Naz salah satu solusi alternatif yang dapat ditawarkan adalah guru harus menggunakan strategi pembelajaran inovatif dan memberikan motivasi untuk melibatkan siswa dalam kegiatan pembelajaran untuk meningkatkan prestasi mereka, Hmadu dan Agustin (Rakhmadhani, Yamtinah, \& Utomo, 2013).

Dalam hal ini, salah satu strategi pembelajaran inovatif yang dapat diterapkan ialah strategi pembelajaran matematika menyenangkan menyenangkan (mms) berbasis metode permainan mathemagic, teka-teki dan cerita matematis. Melalui strategi ini, diharapkan siswa merasa ertarik untuk mempelajari matematika dengan suasana yang menghibur bukan menakutkan siswa.

\section{PEMBAHASAN}

\section{Pengertian Matematika}

Istilah"Matematika" berasal dari kata Yunani "mathein" atau "manthenein" yang artinya "mempelajari". Mungkin juga kata itu erat hubungannya dengan kata sansekerta "medha" atau "widya" yang artinya ialah "kepandaian", "ketahuan", atau "intelegensi". Kata "ilmu pasti" yang selama ini digunakan, timbul sebagai terjemahan dari kata "wiskunde" dalam bahasa Belanda sewaktu panitia istilah bahasa indonesia mulia bekerja di zaman pendudukan jepang. Besar sekali kemungkinannya bahwa kata "wis" telah ditafsirkan sebagai "pasti", karena di dalam bahasa Belanda ada ungkapan "wis en zeker". Memang zeker berarti"pasti". Tetapi wis di sini lebih dekat artinya kepada kata "wisdom" dan "wissenschaft", yang dengan demikian erat pula hubungannya dengan "widya". Oleh karena itu wiskunde sebenarnya harus diterjemahkan sebagai "ilmu tentang belajar" yang sesuai dengan arti "mathein" pada matematika (Kifli \& Usman, 1985).

Barikut ini disajikan beberapa definisi atau pengertian tentang matematika:

1. Matematika adalah cabang ilmu pengetahuan eksak dan terorganisir secara sistematik

2. Matematika adalah pengetahuan tentang bilangan dan kalkulasi

3. Matematika adalah pengetahuan tentang penalaran logik dan berhubungan dengan bilangan.

4. Matematika adalah pengetahuan tentang fakta-fakta kuantatif dan masalah tentang ruang dan bentuk.

5. Matematika adalah pengetahuan tentang struktur-struktur yang logik.

6. Matematika adalah pengetahuan tentang aturan-aturan yang ketat.

Adapun definisi lain dari matematika dapatlah kita ambilkan dari beberapa definisi yang dikemukakan oleh beberapa ahli matematika: 
1. Mathematics is a vast syistem of organized thinking of an analytic and syntetic nature that has developed since the golden. Ages of Greece and the earlier Babylonian civilization.

2. Betrand Russel, Mathematics is a subject in which we never know what we are talking about nor whether what we say it true.

3. D. Hilbert (Wahyuni, 2014), matematika adalah permainan di atas kertas yang menggunakan kaidah-kaidah sederhana dan lambang-lambang yang tak berarti.

Dari berbagai definisi yang telah dikemukakan oleh beberapa ilmuwan diatas tentang matematika, mempunyai makna yang luas sesuai dengan perspektifnya masing-masing.

Banyak perbedaan pandangan para ilmuwan matematika yang sering kita sebut para ahli matematika terdahulu tentang matematika. Misalnya pada tahun 387 Sebelum Masehi (S.M) Plato, seorang filosof yunani, mendirikan sebuah akademi terkenal di athena untuk memenuhi keperluan filosofi dan ilmu pengetahuan. Di atas pintunya tertulis semboyan: "Jangan biarkan orang yang tidak tahu geometri masuk ke sini."

Berikut ini ada beberapa kutipan pandangan dari beberapa para ahli lainnya:

"Matematika adalah ratu dari ilmu pengetahuan dan aritmatika adalah ratu dari matematika." (Karl Freidrich Gauss)

"Tuhan menciptakan bilangan asli, yang lainnya buatan manusia." (Leopoll Kronecker)

"Sediakan aku temapat untuk berdiri dan sebuah tuas yang panjang dan saya akan memindahkan bumi." (Archimedes)

"Bilangan mengatur alm semesta." (Pythagoras)

"Tak ada jalan yang mudah untuk belajar geometri." (Menaechmus)

"Imajinasi lebih penting dari pada pengetahuan." (Albert Einstein)

"Satu hal saya tahu adalah saya tak tahu apa-apa." (Socrates)

"Matematika adalah satu-satunya aktivitas manusia yang tanpa batas." (Paul Erdos)

(Sobel \& Maletsky, 2004)

\section{Strategi Pembelajaran Matematika Menyenangkan}

Pada prinsipnya, pembelajaran dapat diartikan sebagai suatu proses interaksi peserta didik dengan pendidik dan sumber belajar pada suatu lingkungan belajar. Pembelajaran merupakan bantuan yang diberikan pendidik agar dapat terjadi proses pemerolehan ilmu dan pengetahuan, perubahan sikap dan perilaku, serta pembentukan kepercayaan pada peserta didik. Dengan kata lain, pembelajaran adalah proses untuk membantu peserta didik agar dapat belajar dengan baik. Proses pembelajaran dialami sepanjang hayat seorang manusia serta dapat berlaku di manapun dan kapanpun.

Pembelajaran mempunyai pengertian yang mirip dengan pengajaran, walaupun mempunyai konotasi yang berbeda. Dalam konteks pendidikan, guru mengajar supaya peserta didik dapat belajar dan menguasai isi pelajaran hingga mencapai sesuatu objektif yang ditentukan (aspek kognitif), juga dapat mempengaruhi perubahan sikap (aspek afektif), serta keterampilan (aspek 
psikomotor) seseorang peserta didik. Pengajaran memberi kesan hanya sebagai pekerjaan satu pihak, yaitu pekerjaan guru saja. Sedangkan pembelajaran juga menyiratkan adanya interaksi antara guru dengan peserta didik.

Strategi dalam pembelajaran sangat dibutuhkan oleh guru pengajar dalam pemecahan berbagai masalah pembelajaran pada mata pelajaran matematika. Agar anak didik merasa senang, aktif dan tidak merasa tertekan dalam mengikuti proses belajar mengajar matematika di kelas. Sehingga dengan sikap yang demikian guru dan anak didik dapat mencapai tujuan yang di inginkan dalam belajar.

Hal ini didukung dengan apa yang dikemukakan oleh Sobel \& Maletsky (2004) tentang motivasi pengajaran pemecahan masalah bahwa pada permulaan dekade 1980-an, national council of teachers of mathematics (NCTM) menerbitkan sebuah dokumen bejudul "An agenda for action: recommendation for school mathematics of the 1980s". Dokumen ini dirancang sebagai acuan untuk perubahan pengajaran matematika dan dijadikan petunjuk bagi para penulis buku teks oleh berbagai kalangan di seluruh wilayah Amerika Serikat untuk merevisi kurikulum matematika. Rekomundasi pertamanya yang mendapat perhatian dan sambutan yang sangat luas adalah:

\section{a. Pemecahan masalah harus menjadi fokus pada pelajaran matematika di sekolah}

Sebagai hasil Rekomendasi NCTM adalah dalam pemecahan masalah oleh para guru matematika. Pemecahan masalah telah menjadi topik utama diskusi selama dekade 1980-an pada pertemuan-pertemuan profesional, dan sebagai tema utama dari buku teks matematika yang baru. Terkait dengan bukut teks matematika, tentunya tidak lepas dari bagaimana strategi menyelesaikan masalah matematika dapat diselesaikan dalam buku teks tersebut. Menurut Tohir (2017) mengatakan bahwa masalah matematika merupakan suatu masalah yang sifatnya memerlukan penyelesaian dengan teknik tertentu yang disusun secara sistemstis. Kemudian di tahun 1989 NCTM (Council, 1989) mengeluarkan sebuah dokumen berjudul curriculum and evaluation standards for school mathematics yang menjadi acuan untuk perubahan kurikulum selama dekade 1990-an.

\section{b. Pemecahan masalah seharusnya menjadi fokus utama dari kurikulum matematika}

Diantara sekian banyak rekomundasi yang dibuat, mereka menyarankan bahwa perhatian utama harus diberikan pada:

1) Keikutsertaan murid-murid secara aktif dalam mengkonstruksikan dan mengaplikasikan ide-ide dalam matematika

2) Pemecahan masalah sebagai alat dan juga tujuan pengajaran.

3) Pengguanaan bermacam-macam bentuk pengajaran (kelompok kecil, penyelidikan Individu, pengajaran oleh teman sebaya, diskusi seluruh kelas, pekerjaan proyek).

Standar kurikulum dan evaluasi yang dikeluarkan oleh NCTM telah diambil sebagai standar baru untuk pengajaran matematika di banyak negara bagian di Amerika Serikat. Salah satu rekomundasinya adalah bahwa guru-guru mengembangkan bermacam-macam strategi pemecahan masalah, dengan fokus 
pada persoalan yang tidak biasa dijumpai. Banyak daftar tentang strategi pemecahan masalah yang dapat diperoleh.

\section{Metode Permainan Mathemagic}

Mathemagic dapat diartikan sebagai sulap atau permainan matematika yang melibatkan simbol, angka atau bilangan. Menurut (Setyono, 2007), mathemagic adalah suatu pendekatan dan cara pandang baru terhadap matematika terutama dalam menyampaikan materi "materi dasjikan dengan cara yang gembira, kongret dan memperhatikan aspek-aspek psikologis, cara kerja otak ,gaya belajar, dan kepribadian anak didik.

Sebagai sebuah metode permainan, mathemagic dapat diartikan sebagai metode pembelajaran matematika yang menitik beratkan pada pemahaman anak akan konsep dasar matematika yang benar. Metode permainan mathemagic menggunakan berbagai macam permainan seperti simbol, angka dan bilangan sehingga menjadi suatu pengalaman yang menyenangkan bagi anak. Karena pembelajaran yang dilkukan dngan hati yang riang gembira akan meninggalkan kesan yang mendalam sehingga anak akan leboh mudah memahami pelajaran yang diberikan.

Menurut Learning Teoris and Educational Perspective (Schunk, 2012) menyatakan bahwa "permainan juga mempengaruhi pembelajaran dengan meningkatkan motivasi. Motivasi semakin besar ketika hubungan endogenous (alamiah) muncul diantara konten dan makna (pengaruh khusus), dimana permainan atau simulasi menampilkan konten.". Dalam proses pembelajarannya, metode mathemagic akan meningkatkan rasa percaya diri anak sehingga mereka akan mampu dan berani untuk mengerjakan soal dan mencoba untuk menyelesaikannya. Selain itu, metode mathemagic dapat menumbuhkan daya minat atau antusias siswa dalam mempelajari matematika.

Melalui metode mathemagic diharapkan menjadi solusi cerdas dan efektif untuk mengatasi berbagai masalah (problems) pembelajaran matematika pada siswa. Dengan metode yang efektif dan menyenangkan dapat menumbuhkan konsep diri positif dan sehat yang mempunyai peran penting dalam menentukan keberhasilan siswa dimasa depan. Mathemagic membantu siswa menjadi suka, senang, dan jago matematika, kreatif, bahagia, dan senang belajar serta memiliki karakter tersendiri, karena mathemagic menekankan pada konsep dasar matematika yang kuat dengan cara penyampaian yang menyenangkan dan sesuai dengan pola pikir siswa. Mathemagic membantu siswa untuk memiliki kosep diri dan kepribadian yang jauh lebih baik.

Adapun karakteristik dari metode mathemagic yaitu:

1. Didasari atas rasa keingintahuan siswa terhadap mathemagic. Guru menstimuli aatau mengenalkan kepada siswa bahwa matematika itu bisa dibuat permainan yang menyenangkan atau bisa dibuat sulap. Jadi, siswa merasa penasaran dan tertarik untuk mempelajarinya.

2. Sikap spontan dan suka rela. Kata lainnya, keinginan siswa sendiri untuk terlibat dalam permainan atau menyaksikan seprti apa mathemagic itu.

3. Senantiasa melibatkan peran aktif dari siswa, baik aktif secara mental maupun fisik. 
4. Memiliki korelasi yang relevan dengan kemampuan kreatif, memecahkan masalah, kemampuan berbahasa, kemampuan memperoleh teman sebanyak mungkin, kepercayaan yang tinggi, dan lain sebagainya.

Metode mathemagic memiliki tujuan pembelajaran yang ingin dicapai, yaitu:

1) Untuk mengubah persepsi negatif siswa menjadi persepsi yang positif terhadap mata pelajaran matematika. Sehingga matematika tidak monoton dipandang sebagai sebuah pelajaran yang sulit, jelimet dan menyebalkan

2) Untuk menumbuhkan dan meningkatkan rasa ketertarikan siswa pada matematika

3) Untuk menumbuhkan rasa percaya diri

4) Untuk menggali dan melatih kemampuan berpikir, pemecahan masalah, berbahasa dan berkomunikasi

5) Untuk meningkatkan prestasi belajarnya, dan

6) Untuk menghayati keterkaitan antara matematika dengan berbagai benda atau kejadian dalam kehidupan sehari-hari

Banyak macam manfaat yang dapat diambil dari penggunaan metode mathemagic dalam pembelajaran di kelas sekolah. salah satu di antaranya ialah dapat merangsan siswa untuk senang dan tekun mempelajari matematika. Selain itu, siswa dapat meningkatkan segala kemampuan yang dimiliki atas suatu peristiwa yang interaktif dalam permainan mathemagic.

Berikut dipaparkan beberapa mathemagic yang dapat diterapkan dalam pembelajaran matematika di sekolah:

\section{Mathamegic 1: Menebak Angka Pada Kartu}

Permainan mathemagic ini sangat interaktif karena melibatkan media kartu remi atau kartu lainnya yang dapat dibuat sendiri semenarik mungkin, sehingga dapat menggugah minat siswa dalam mempelajari matematika yang aplikatif.

Langkah-langkah

a. Suruhlah penonton untuk mengambil 9 kartu secara acak dari kumpulan kartu yang tersedia!

b. Kemudian suruhlah untuk membuka satu kartu, dikumpulkan dan dikocok bersama dengan kartu lainnya

c. Selanjutnya, kamu ambil 9 kartu tersebut, lalu membaginya menjadi 3 tumpukan

d. Setelah itu, tiap tumpukan di buka dan ditanyakan kepada orang yang membuka kartu semula. Apakah kartunya ada di tumpukan ini atau tidak?

e. Letakkan tumpukan kartu yang ada di tengah-tengah tumpukan lainnya

f. Lakukan 1 kali pertanyaan sekali lagi

g. Langkah terakhir adalah mengambil kartu paling tengah dari kartu yang telah dijawab ada pada tumpukan tersebut dan katakan bahwa kartu yang diambil/didilihat semula adalah kartu tersebut.

\section{Mathamegic 2: Menebak Sebarang Angka Dengan Mata Tertutup}

Trik- trik yang digunakan dalam mathemagic ini sungguh sangat spektakuler. Karena dalam atraksi ini anda dituntut untuk bisa menebak angka-angka yang dituliskan oleh orang lain dengan mata tertutup, baik menggunakan kain atau benda lainnya. Sebenarnya trik-trik ini sangatlah sederhana. Tetapi dengan 
kemasan yang indah dan unik dapat menggoda penonton untuk takjub dan senang terhadap mathemagic ini.

Langkah-langkah

a. Sediakanlah kotak yang banyaknya lebih dari atau sama dengan 1 dan kurang dari atau sama dengan $(1 \leq \mathrm{k} \leq 9)$. Kemudian, 3 kotak untuk jawaban dari ke 3 pertanyaan yang semula. Lalu, 3 kotak berikutnya untuk jawaban dari ke 3 pertanyaan yang terakhir. Bila ingin terlihat dahsyat, anda harus menawarkan ke penonton untuk memilih angka-angka yang mereka sangat suka dengan dimulai dari 1 sampai 11.

b. Mintalah kepada siswa untuk mengisi setiap kotak yang telah disediakan dengan sebarang angka yang mereka suka. Dalam memilih angka-angka tersebut bebas dengan catatan angka nol termasuk bilangan genap.

a. Ajukanlah pertanyaan sebanyak 3 pertanyaan dan jawabannya dituliskan pada setiap kotak yang telah disediakan sebelumnya.

b. Ulangi sekali lagi ke 3 pertanyaan tersebut dan jawabannya dituliskan pada setiap kotak yang telah disediakan sebelumnya.

c. Kemudian tebaklah hasil akhirnya.

Untuk menebak hasil akhir dari mathemagic tersebut, terlebih dahulu anda harus tahu bahwa hasilnya akan mengikuti ke 3 pertanyaan yang diajukan. Karena apabila pertanyaan-pertanyaannya dimulai dari:

- Ada berapakah angka ganjil pada kotak-kotak tersebut?

- Ada berapakah angka genap pada kotak-kotak tersebut?

- Ada berapakah angka keseluruhan pada kotak-kotak tersebut? Selanjutnya mengulang ke 3 pertanyaan tersebut di ulang sekali lagi dan jawabannya dituliskan pada ke 3 kotak terakhir.

- Ada berapa angka ganjil pada kotak-kotak tersebut?

- Ada berapa angka genap pada kotak-kotak tersebut?

- Ada berapa angka keseluruhan pada kotak-kotak tersebut?

Maka akan diperoleh angka-angka akhir 2, 1, dan 3, Sehingga setelah semua pertanyaannya dijawab dengan benar oleh penonton yang maju, maka katakan dengan suara keras sambil mensimbolkan dengan jar-jari anda bahwa pada ketiga kotak yang terakhir angka-angkanya adalah 2, 1, dan 3. Sangat indah dan spektakuler bukan...?.begitu juga sebaliknya apabila pertanyaan dimulai dari:

- Ada berapa angka genap pada kotak-kotak tersebut?

- Ada berapa angka ganjil pada kotak-kotak tersebut?

- Ada berapa angka keseluruhan pada kotak-kotak tersebut? Selanjutnya mengulang ke 3 pertanyaan tersebut di ulang sekali lagi dan jawabannya dituliskan pada ke 3 kotak terakhir.

- Ada berapa angka genap pada kotak-kotak tersebut?

- Ada berapa angka ganjil pada kotak-kotak tersebut?

- Ada berapa angka keseluruhan pada kotak-kotak tersebut?

Maka akan diperoleh angka-angka akhir 1, 2, dan 3, Sehingga setelah semua pertanyaannya dijawab dengan benar oleh penonton yang maju, maka katakan dengan suara keras sambil mensimbolkan dengan jar-jari anda bahwa pada ketiga kotak yang terakhir angka-angkanya adalah 1, 2, dan 3. Sangat indah dan menakjubkan bukan?. 


\section{Menebak Angka Pada Kalender}

Langkah-langkah

a. Mintalah siswa secara sukarela untuk memegang sebuah kalender

b. Suruhlah ia membuat persegi pada kalender, yang berukuran 3 × 3 angka kalender

c. Mintalah siswa lain untuk menyebutkan jumlah angka terkecil dan terbesar dalam kotak yang ia buat. Dalam contoh ini adalah $32=(8+24)$

d. Dalam pikiran guru, kurangi angka yang ia sebutkan dengan 16, lalu bagi dengan 2. Dalam kasus ini, $32-16=16,16: 2=8$. Angka pada point nomor 4 ini kita sebut sebagai " $d$ ".

e. Untuk mengetahui angka - angka lain yang terdapat dalam persegi yang ia buat pada kalender tersebut, gunakan rumus berikut:

Tabel 1 Rumus Menebak Angka Pada Kalender 3 × 3

\begin{tabular}{|c|c|c|}
\hline$d$ & $d+1$ & $d+2$ \\
\hline$d+7$ & $d+8$ & $d+9$ \\
\hline$d+14$ & $d+15$ & $d+16$ \\
\hline
\end{tabular}

Ganti saja “ d " dengan angka yang anda dapatkan pada point nomor 4 . Dalam contoh kali ini, ganti " $d$ " dengan 8.

f. Sebutkan satu persatu angka-angka pada kalender seolah-olah kita sedang membaca pikirannya Pasti hasilnya akan tepat. Atau bila ingin terlihat spektakuler, mintalah pada siswa untuk menyebutkan pada kotak keberapa angka yang ingin ditebak. Dengan catatan, terlebih dahulu kita menyediakan kotak persegi 3 x 3 dan diberi nomor urut dari satu sampai sembilan $(1-9)$. Seperti tampak pada gambar berikut ini.

Tabel 2 Rumus Menebak Angka Pada Kalender 3 × 3

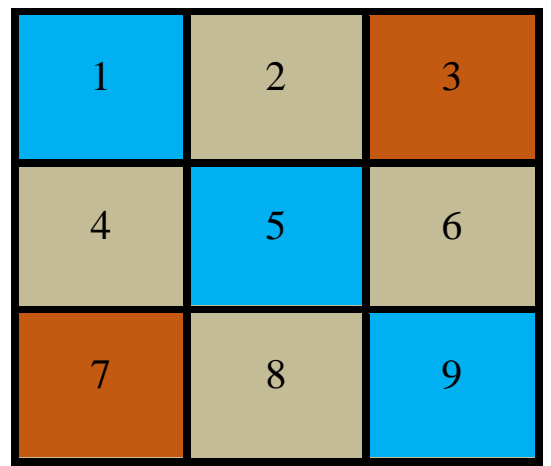

Sumber: (Maswar, 2011) 


\section{Metode Permainan Teka-teki Matematis}

Teka-teki matematika penting untuk diterapkan sebagai sebuah metode pembelajaran dalam kelas matematika. Permainan teka-teki dapat melatih kemampuan berpikir dan bernalar siswa terhadap sebuah permasalahan matematika maupun lainnya. Pemahaman konsep matematika siswa dengan menerapkan strategi teka-teki silang lebih baik daripada pemahaman konsep matematika siswa yang menerapkan pembelajaran konvensional. Dengan demikian, strategi teka teki silang dapat meningkatkan pemahaman konsep siswa (Edriati, Handayani, \& Sari, 2017).

Langkah-langkah metode teka-teki sebagai berikut:

1. Mencurahkan gagasan teka-teki yang ingin diberikan kepada siswa

2. Susunlah teka teki tersebut sekreatif dan semenarik mungkin, atau paling tidak terbaru yang masih belum banyak diketahui siswa

3. Bagikan teka-teki kepada siswa baik secara individu maupun kelompok diskusi

4. Mintalah siswa untuk menyelesaikan teka-teki tersebut secara cepat

5. Tentukan batasan waktu. Serahkan hadiah kepada individu atau kelompok siswa yang paling cepet dan paling tepat menyelesaikan teka-teki tersebut.

Adapaun tujuan dari permainan teka-teki matematis ini, yaitu:

1. Untuk memotivasi siswa senang pada mata pelajaran matematika

2. Untuk menumbuhkan dan meningkatkan kreativitas siswa pada matematika

3. Untuk menumbuhkan rasa percaya diri siswa

4. Untuk menggali dan melatih kemampuan berpikir, dan pemecahan masalah siswa

5. Untuk meningkatkan prestasi belajarnya, dan

6. Untuk menghayati keterkaitan antara matematika dengan berbagai benda atau kejadian dalam kehidupan sehari-hari

Beberapa teka-teki matematis yang dibahas dalam tulisan ini yaitu sebagai berikut:

\section{Teka-teki 1}

Teka-teki ini sangat buming sebagai uji kecerdasan para pengguna media seperti face book, instragram, whatsapp dan media lainnya. Seperti halnya tekateki yang diungkap oleh liptan 6 com jakarta (Lumbantobing, 2017) soal ujian itu bisa juga membuat para netizen kebingungan mencari cara penyelesaian yang mengharuskan para penjawab berpikir secara tidak biasa (out of the box). Sekarang ini bertebaran "uji kecerdasan" di medial sosial, termasuk Facebook. Apakah kita mengerti cara melakukannya?Salah satu teka-teki yang dimaksud mensyaratkan para pengguna agar melengkapi beberapa urutan angka dengan pola tertentu. Menurut para pembuat soal, hanya 1 di antara 1.000 orang yang mampu menemukan dua solusi berbeda untuk soal yang diberikan.

Dalam setiap kasus matematika di sekolah, umumnya hanya terdapat satu jawaban benar untuk pemecahan soal-soal matematika. tetapi pada kasus teka-teki ini, terdapat dua solusi yang lazim ditemukan sebagai jawaban yang logis. Tekateki ini sangat menarik untuk diterapkan di kelas matematika sekolah, dengan maksud memotivasi siswa untuk antusias belajar matematika. selain itu, 
dimasudkan untuk melatih kemampuan berpikir dan pemecahan masalah. Yang tidak kalah pentingnya juga ialah untuk melatih mental dan kepercayaan diri siswa dalam menghadapi soal-soal matematika yang diberikan guru.

Teka-teki ini mensyaratkan siswa melihat suatu aturan yang diterapkan pada baris pertama sebagai suatu kelaziman yang formal dalam operasi penjumlahan. Kemudian menerapkan aturan itu pada baris-baris berikutnya. Jika aturannya benar, siswa akan menjawab/memperoleh hasil seperti yang tertera pada baris pertama, kedua, hingga pada baris terakhir.

\section{$1+4=5$ \\ $2+5=12$ \\ $3+6=21$

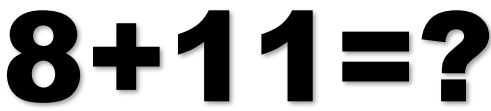

Teka-teki di atas mengisaratkan bahwa siswa dituntut untuk berpikir cerdas berkenaan dengan jawaban dari 8+11.

Adapun cara penyelesaian dari teka-teki ini, ialah ada dua cara yang lazim diteukan. Kedua cara tersebut yaitu:

1. Siswa setuju bahwa $1+4=5$ tanpa perlu banyak perdebatan karena ini sudah sesuai prosedur penjumlahan. Kemudian, siswa akan melakukan penjumlahan $2+5$ ke angka 5 dari baris atas agar mendapatkan jawaban ke dua yaitu 12 . Dengan mengikuti pola logis itu, maka pada baris ke tiga mereka akan melakukan penjumlahan $3+6$ untuk mendapatkan 9. Selanjtnya, angka 9 ditambahkan kepada angka 12 untuk mendapatkan angka 21. Akhirnya, siswa melakukan penjumlahan $8+11$ dalam persamaan terakhir, dan mendapatkan angka 19. Lagi-lagi, hasil itu ditambahkan ke jawaban sebelumnya yakni 21, sehingga total akhirnya adalah 40. Ternyata, itu bukanlah satu-satunya cara memecahkan soal tersebut.

2. Teka-teki itu menyebutkan bahwa jelaslah $1+4=5$, tapi angka 5 itu dapat juga diperoleh dengan menambahkan 1 kepada perkalian 4 x 1 . Dengan aturan demikian, maka baris ke dua dijawab dengan menambahkan angka 2 kepada 2 $x$ 5, sehingga mendapat angka 12 seperti diperlihatkan dalam gambar.Pada baris ke-3, kita menambahkan angka 3 kepada $6 \times 3$ sehingga mendapatkan angka 21. Dengan demikian, untuk baris terakhir pada soal itu, orang menambahkan 8 kepada 11 x 8 sehingga mendapatkan jawaban akhir yaitu 96. 


\section{Teka-teki 2}

Teka-teki kedua ini sangat penting diterapkan kepada siswa untuk melatih kemampuan bernalar, kemampuan menganalisis, dan kemampuan dalam pemecahan masalah. Jenis teka-teki ini membutuhkan tingkat berpikir esktra dan tentunya membutuhkan daya kreatifitas yang tinggi juga. Teka-teki ini dinamai "empat empat" (4444). Penggunaan empat empat, kita bisa mendapatkan bilangan apa pun juga.

Pada teka-teki ini, siswa diminta untuk memperoleh bilangan 0 hingga 10 atau bahkan hingga bilangan 100, dengan menggunakan empat empat. Melalui teka-teki ini, siswa akan berpikir dan akan berusaha secepat mungkin untuk menemukan solusinya. Ini layak untuk dijadikan kuis cerdas, cepat dan tepat untuk menstimuli pembelajaran pada kelas matematika di sekolah.

1. Untuk memperoleh $0=$

2. Untuk memperoleh $1=$

3. Untuk memperoleh $2=$

4. Untuk memperoleh $3=$......., dan seterusnya

Sebagai contoh. Bagamana memperoleh bilangan 10 dengan menggunakan $4444 ?$

Solusi dari teka-teki ini ialah:

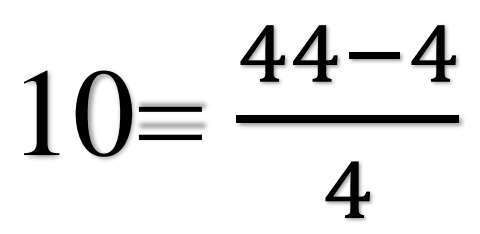

\section{Metode Cerita-cerita Matematis}

Metode bercerita adalah cara penyampaian atau penyajian materi pembelajaran secara lisan dalam bentuk cerita dari guru kepada anak didik. Dalam kegiatan pelaksanaannya metode bercerita dilaksanakan dalam upaya memperkenalkan, memberikan keterangan, atau penjelasan tentang hal-hal baru dalam rangka menyampaikan pembelajaran yang dapat mengembangkan berbagai kompetensi dasar, Dhieni dalam (Tambak \& Muhammad, 2016).

Metode bercerita yaitu menampilkan cerita-cerita matematis yang isnpiratif dan menarik pada kelas pembelajaran matematik di kelas sekolah. Hal ini penting diberikan kepada siswa, agar mereka termotivasi belajar matematika dan tidak melupakan sejarah ataupun keindahan-keindahan dari hikmah mempelajari matematika itu sendiri. Ada sekian banyak cerita-cerita matematis yang mungkin dapat diceritakan kepada siswa sebagai stimulis proses pembelajaran di kelas matematika. Cerita-cerita tersebut bisa dikemas sedemikian menarik dan lucu sehingga siswa merasa terhibur.

Memberikan cerita-cerita matematis pada siswa dapat menarik perhatian dan merangsang otak mereka sehingga bekerja dengan baik. Karena dengan mendengarkan cerita, siswa akan merasa senang sekaligus menyerap nilai-nilai /hikmah inspiratif dari cerita-cerita itu. erita tentang kisah-kisah yang 
mengandung hikmah sangat efektif untuk menarik perhatian anak dan merangsang otaknya agar bekerja dengan baik, bahkan metode ini dianggap yang terbaik dari cara-cara yang lain dalam mempengaruhi pola bantu anak (Tambak \& Muhammad, 2016).

\section{Contoh Cerita Matematis}

Cerita ini tentang 35 unta yang dibagi di antara tiga laki-laki Arab bersaudara. Bagaimana Bremiz Samir, yang dikenal sebagai laki-laki penghitung membuat suatu pembagian yang tampaknya mustahil sehingga membuat laki-laki bersaudara yang sebelumnya bertengkar merasa puas sepenuhnya. Keuntungan yang tak diduga diberikan kepada Bremiz Samir melalui transaksi ini.

Dekat dengan sebuah losmen tua yang setengah dibiarkan, Bremis Samir dan temannya yang bernama Hanak Tade Mania melihat 3 orang laki-laki yang saling berbantahan dengan sengit di samping sekumpulan unta. Di antara sorak dan hinaan, orang-orang mengisyaratkan dengan ramai di dalam debat yang sengit, Bremiz dan Hanak mendengar teriakan kemarahan mereka. " Itu tidak bisa!", " Itu adalah perampokan!", “Tetapi aku tidak setuju!" . Bremiz yang cerdas sebagai seorang ahli aljabar terpecaya, bertanya kepada mereka mengapa mereka bertengkar. Merka pun menjawab "kami bersaudara," yang paling tua mengatakan dan kami menerima 35 unta ini sebagai warisan kami. Menurut pernyataan keinginan ayahku, separuh hewan-hewan itu kepunyaanku, sepertiga untuk saudaraku Hamed, dan sepersembilan untuk Harim (yang paling muda). Meskipun demikian, kami tidak mengetahui bagaimana cara membuat pembagian itu dan apa pun juga salah satu dari kami menyarankan, dua yang lain berselisih. Dari penyelesaian yang dicoba sejauh ini, tidak ada satu pun yang bisa diterima. Jika separuh 35 adalah 17,5, maka jika tidak sepertiga maupun sepersembilannya dari jumlah ini adalah suatu jumlah yang tepat, kemudian bagaimana mungkin kita membuat pembagian itu?". "Sangat sederhana, kata Bremiz. "Aku berjanji untuk membuat pembagian dengan wajar, tetapi beri aku kesempatan untuk menambah 35 unta warisan tersebut dengan satu unta yang membawa kami ke sini. Hanak kaget, karena untanya akan ditambahkan kepada unta warisan 3 bersaudara. "Dalam posisi ini aku turut campur "tetapi aku tidak bisa mengizinkan kegilaan seperti itu. Bagama kami akan melanjutkan perjalanan jika kami ditinggalkan tanpa seekor unta?", "tenang saudaraku”, kata Bremiz. Selanjutnya, Bremiz melakukan pembagian sebagai berikut: "sekarang unta telah menjadi 36. Untuk saudara yang sulung, seperti pesan ayahmu separuh menjadi bagianmu. Jadi engkau mendapatkan $1 / 2$ dari 36 yaitu 18 ekor. Anda tidak boleh mengeluh dan menolak dengan alasan apapun, karena Anda diuntungkan dalam kasus ini. Seharusnya Anda memperoleh 17,5 ekor dari jumlah unta warisan tetapi sekarang memperoleh 18 ekor. Kemudian Bremiz melanjutkan kepada Hamed, Anda memperoleh 1/3 dari 36 yaitu 12. Anda juga tidak boleh menolak, karena seharusnya Anda memperoleh 11,7 dari 35 ekor unta warisan. Lalu, mengarah kepada Harim sebagai saudara termuda, sekarang Anda memperoleh 4 ekor unta. Anda harus tidak punya alasan yang kuat untuk menolaknya, karena sesuai pesan ayahmu 1/9 menjadi bagianmu, dimana seharusnya 3,9 dari 35. Sekarang anda telah memperoleh 4 ekor. Dengan pembagian yang saling menguntungkan ini, 18 unta kepunyaan paling tua, 12 unta yang berikutnya dan 4 unta kepunyaan yang 
paling muda, bila ditambahkan $18+12+4=34$ unta. Dari 36 unta, oleh karena itu, ada 2 ekstra. Satu seperti Anda ketahui, kepunyaan temanku Hanak. Yang lain sudah pada tempatnya kepunyaanku, karena aku telah menyelesaikan problem yang rumit tentang warisan untuk kepuasan semua orang".

Dari cerita di atas, dapat diambil beberapa hikmah yang dapat menginsipirasi para guru dan siswa. Persoalan pesan warisan yang rumit dapat dipecahkan dengan mudah oleh orang Bremiz yang ahli dalam matematika aljabar. Tentunya cerita ini hanya sebagi contoh salah satu cerita matematis yang dapat diceritakan kepada siswa dalam kelas matematika. selain itu masih banyak cerita-cerita matematis yang dapat diceritakan, misalnya tentang simbol matematika yang dapat mencegah perceraian, seorang anak dan profesor sains, dan lain-lain.

\section{KESIMPULAN DAN SARAN}

Berdasarkan pada tujuan dan pembahasan yang dikemukakan pada bagian sebelumnya dapat disimpulkan bahwa untuk memotivasi siswa menyukai matematika dapat diterapkan strategi pembelajaran matematika menyenangkan siswa (MMS) berbasis metode permainan mathemagic, teka-teki matematis, dan cerita-cerita matematika yang menarik, menantang dan menghibur. Dengan demikian, pembelajaran di kelas matematika menjadi nyaman, dan tidak kaku. Selain itu, melalui metode-metode tersebut dapat merangsang siswa tertarik belajar matematika dan merangsang otak mereka untuk berpikir kreatif. Belajar menjadi terhibur, dan persepsi siswa terhadap matematika yang selama ini negatif karena dipandang rumit, jelimet, terlalu serius dan membosankan menjadi persepsi positif yakni matematika itu asyik, mudah, banyak manfaatnya, menghibur dan menyenangkan.

Strategi MMS ini sangat tepat digunakan dalam pembelajaran matematika di kelas sekolah, baik sekolah dasar, sekolah menengah pertama, sekolah menengah atas serta sejenisnya. Melalui penerapan strategi MMS, belajar matematika menjadi menarik, asyik dan menyenangkan serta bermanfaat untuk kehidupan sehari-hari.

\section{DAFTAR PUSTAKA}

Council, N. R. (1989). Curriculum and evaluation standards for school mathematics. National Council of Teachers of Mathematics.

Edriati, S., Handayani, S., \& Sari, N. P. (2017). Penggunaan Teka-Teki Silang Sebagai Sebagai Strategi Pengulangan Dalam Meningkatkan Pemahaman Konsep Matematika Siswa Sma Kelas Xi Ips. Jurnal Pelangi, 9(2), 71-78. https://doi.org/10.22202/jp.2017.v9i2.2047

Kifli, B., \& Usman, M. (1985). Prinsip-Prinsip Matematika. Sinar Baru. Bandung.

Kritiyono, H. (2008). Penelitian Mahir Perkalian dan Pembagian Bilangan Dasar Mahir Perkalian dan Pembagian Bilangan Dasar Melalui Metode Permainan Kartu. Jurnal Pendidikan, (10), 115.

Lumbantobing, A. (2017). Bisakah Anda Pecahkan Teka-Teki Matematika Menghebohkan Ini? Liputan 6: 
https://www.liputan6.com/global/read/3026666/bisakah-anda-pecahkanteka-teki-matematika-menghebohkan-ini [Diakses 26/11/2019. 16:49].

Maswar. (2011). Mathemagic: Pintar Matematika Pintar Bersulap. Yogyakarta: Absolute Media.

Rakhmadhani, N., Yamtinah, S., \& Utomo, S. B. (2013). Pengaruh penggunaan metode teams games tournaments berbantuan media teka-teki silang dan ular tangga dengan motivasi belajar terhadap prestasi siswa pada materi koloid kelas XI SMA Negeri 1 Simo tahun pelajaran 2011/2012. Jurnal Pendidikan Kimia, 2(4), 190-197.

Rosa, E. (2017). Pengaruh Penerapan Model Pembelajaran Matematika Knisley (MPMK) Menggunakan Media Petak Warna-Warni Terhadap Kemampuan Pemahaman Matematis Siswa Dalam Pembelajaran Segitiga di Kelas VII MTs. Putra-Putri Simo. INSPIRAMATIKA: Jurnal Inovasi Pendidikan Dan Pembelajaran Matematika, 3(1), 43-52.

Safari, M. A. (2005). Penulisan butir soal berdasarkan penilaian berbasis kompetensi. Jakarta: APSI Pusat.

Samsudin, M. A., Tarbiyah, F., \& Situbondo, I. S. (2018). Peranan motivasi dalam kerajinan belajar siswa. Edupedia, 3(1).

Schunk, D. H. (2012). Learning theories: an educational perspective 6th ed. Terjemahan Hamdiah \& Rahmat Fajar). Yogyakarta: Pustaka Pelajar.

Setyono. (2007). Matchmagic Untuk Pembelajaran Menyenangkan. Jakarta: Yudhistira.

Sobel, M. A., \& Maletsky, E. M. (2004). Mengajar Matematika. Jakarta: Erlangga.

Suwarno, M. (2016). KOMBINASI QUANTUM LEARNING DAN MEDIA MOTIVASI “ MATHEMAGIC " UNTUK MENINGKATKAN MINAT DAN HASIL. Prosiding Seminar Nasional Pendidikan Matematika 2016, 1, 128-137. Malang: Universitas Kanjuruhan Malang.

Tambak, S., \& Muhammad, N. (2016). Metode Bercerita dalam Pembelajaran Pendidikan Agama Islam SYAHRAINI TAMBAK. Jurnal Pendidikan Agama Islam Al-Thariqah, 1(1), 1-26.

Thalhah, S. Z., Tohir, M., Nguyen, P. T., Shankar, K., \& Rahim, R. (2019). Mathematical Issues in Data Science and Applications for Health care. International Journal of Recent Technology and Engineering, 8(2S11), 41534156. https://doi.org/10.35940/ijrte.B1599.0982S1119

Tohir, M. (2017). Pengembangan Bahan Ajar Olimpiade Matematika Berdasarkan Model Pemecahan Masalah untuk Meningkatkan Kemampuan Penalaran Matematis Siswa. In Tesis. Magister Pendidikan Matematika Universitas Jember. Jember: Program Pascasarjana Universitas Jember.

Wahyuni, S. (2014). MENINGKATKAN KEMAMPUAN ANALISIS MATEMATIK SISWA SMP MELALUI STRATEGI PEMECAHAN MASALAH BERBANTUAN DIAGRAM $V E E$. Univeritas Pendidikan Indonesia. 